\title{
Paczolay Gyula
}

\section{Baranyai Decsi Csimor János, a szóláskutató}

1598 nevezetes és alapvető évszám a magyar közmondások és szólások történetében. Ebben az évben jelent meg az észak-magyarországi Sáros megyei Bártfán, a Klöß Nyomdában az első magyar gyüjtemény, Baranyai Decsi Csimor Jánosnak, a székelyvásárhelyi schola particula tudós rektorának Adagiorum graecolatinoungaricorum chiliades quinque (röviden: Adagiorum), azaz „Ötezer görög-latin-magyar szólás gyüjteménye” címü munkája (BD). A kisalakú (12-ed rét) 444 oldalas kötetben a Varkucz Györgynek szóló ajánlást az olvasókhoz (Benevolo lectori) szóló 16 oldalas latin nyelvü elöszó követi, a végén pedig Balog János 20 soros latin verse (In Zoilum) olvasható.

A könyv talán 200-300 példányban jelent meg, és hamar ritkasággá vált. Szenci Molnár Albert Magyar-latin szótára második kiadásában számos közmondást közöl Baranyai Decsi gyüjteményéből, amint erre az előszóban hivatkozik is. Ö azonban valószínüleg egy címlap nélküli vagy hiányos címlapú példányt kapott, ezért téves címet közölt (Libellus Adagiorum Latino Ungaricorum). Geleji Katona István püspök, a Magyar grammatikatska (Gyula-FejerVaratt, 1645) szerzője nem ismerte. Bod Péter a Magyar Athenasban (Szeben, 1766. 68-69.) a Szenci Molnár Albert által megadott címet közli, és 1588-as strasbourgi kiadásról ír, tehát ő sem látott teljes példányt belöle. Erdélyi János 1851-ben kiadott Magyar közmondások könyve címü gyüjteményének (EJ) végén olvasható Közmondásokrul szóló tanulmányában, a 449. oldalon leírja, hogy „én e könyvet nem láttam”. Csak 1850-ben került elö egy Ballagi Mór által leírt „,ismeretlen gyüjtemény”, amelyet a következő évben Lugossy József Baranyai Decsi köteteként azonosított. Még ezt követően is sokáig Szenci Molnár Albertnek (SzM) vagy Kis-Viczay Péternek (KV) tulajdonították Baranyai Decsi közmondásait.

A kötet előszavában Decsi felsorolja a régebbi szólásgyüjtőket a bibliai Példabeszédek könyve szerzőjének tekintett Salamon királytól kezdve Laertiuson, Theophrasztoszon és Didimuszon át Rotterdami Erasmusig, mellette megemlítve a 16. századi Hadrianus Iuniust és Gilbertus Cognatust is. A közmondások hasznaként kiemeli jelentőségüket a filozofálásban, a meggyőzésben és a közmondásokat sokszor csak rövidítve vagy utalással említő írók megértésében. Felhívja a figyelmet arra is, hogy csak mértékkel használjuk őket, ne „ételként”, hanem csak „füszerként”, mert halmozásuk többet árt, mint használ, és gonddal illesszük öket be a beszédünkbe. Megjegyzi azt is, hogy több nyelvben találunk azonos közmondásokat.

Ma a Decsi-kötetnek négy teljes (kettő Budapesten, egy-egy Késmárkon, illetve Kolozsvárott) és tíz többé-kevésbé hiányos példányáról tudunk, amelyek közül egy-egy található például Kolozsvárott, Marosvásárhelyt, Nagyenyeden, Nagyszebenben és Sárospatakon is. 1978-ban az ELTE Magyar Nyelvészeti Tanszékcsoportja 400 példányban hasonmás kiadást készített belöle. 


\section{Az Adagiorum helye más nyelvek szólásgyüjteményei között}

Ha azt vizsgáljuk meg, hogy különböző nyelvek első szólás- és közmondásgyüjteménye mikor jelent meg, akkor azt találjuk, hogy Baranyai Decsi János munkáját Közép- és Kelet-Európában csak egy cseh gyüjtemény előzte meg. Részletesebben a következő adatokat kapjuk:

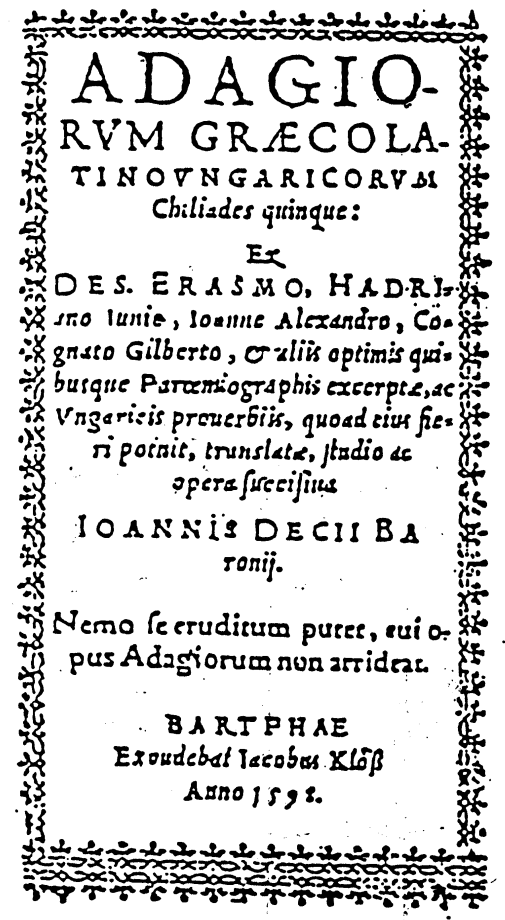

11. századi az első angol (Durham Proverbs) és török (Mahmud al-Kasgari, 1073-1074), 12. századi az első arab (AlMaidani, 1124 előtt), 13. századi az első olasz és francia gyüjtemény. A 14. században jött létre az első német (Schwabacher Sprüche) és spanyol, a 15.ben az első svéd, a 16.-ban az első dán és 1571 előtt az első cseh gyüjtemény (Červenka-Blahoslav).

Az Adagiorumot 1618-ban követte az első lengyel (Samuel Ryśinski), majd 1653-ban az első litván, 1660-ban az első észt (H. Göseken), a 17. század végén az első ukrán (Zinovjev) gyüjtemény. 18. századi az első finn (H. Florinus 1702), orosz, szerb és szlovák, a 19. században jelent meg az első ismert bolgár, román és szlovén gyüjtés.

\section{8 elötti magyar adatok}

Természetes, hogy már Decsi gyüjteményének a megjelenése előtt is találunk magyar közmondásokat és szólásokat például irodalmi alkotásokban, levelekben. Ezek túlnyomó többsége (kb. 100) megjelenik az Adagiorumban is. A legfontosabb korábbi források: Heltai Gáspár: Száz fabula (Colosvarot 1566), és Szegedi Lőrinc: Theophania (Debrecen 1575). Érdemes megemlíteni még a következő forrásokat, illetve szerzőket: Salamon kiralynac, az David kiraly fianak Markalffal valo trefa beszedeknec rouid könyue (Colosuáratt 1577), Balassi Menyhárt árultatása (Abrudbánya 1569), Pesti Gábor: Esopus fabulaij (Bécs 1536), Tinódi: Cronica (Colosvarba 1554), Heltai Gáspár: Chronica (Colosvarot 1575), valamint Balassi Bálint, Bornemissza Péter, Dávid Ferenc, Méliusz Juhász Péter és Sztárai Mihály müveit. Jó néhány adatot találunk levelezésekben (pl. Báthory István leveleiben) és Szabó T. Attila föleg kéziratos anyag alapján összeállított Erdélyi Magyar Szótörténeti Tár c. sorozatának eddig megjelent tíz kötetében (SzTA).

Pelei Tamás gyulafehérvári kanonok 1515-ben Budán vásárolt egy 1508-as velencei Aldus kiadású Erasmus: Adagiorum chiliades tres ac centuriae című kötetet. Ebbe - feltehetően 1515 és 1540 között - számos glosszát, köztük néhány közmondást is beírt. Ilyenek például a következők: Lassan sijes (112r), Penz emberseg Ruha tiztesség (194r), Zemermes deaknak ijres thaskaia $(194 \mathrm{v})$.

Decsi említi, hogy korábban már Siklósi Miklós is gyüjtött közmondásokat, de ezt a gyüjteményt már ő sem ismerte, és azóta sem került elő. 


\section{Az Adagiorum mintája}

Az Adagiorum mintája, amint ezt már 1911-ben Tolnai Vilmos megállapította (TV-2), egy 1574-ben Bázelben kiadott Des. Erasmi Roterodami Adagiorvm chiliades qvatvor cvm sesquicentvria..., azaz „Rotterdami Erasmus 4150 szólása” címü gyüjtemény volt (ErAd). Ez a kötet Erasmus (1466/1469-1536) 4150, magyarázattal ellátott szólása mellett jó néhány más neves 16. századi szólásgyüjtő, többek között Hadrianus Iunius, Ioannes Alexandrus, Gilbertus Cognatus, Caelius Rhodiginus, Petrus Godofredus és mások szólásjegyzékét is tartalmazza. Ehhez hozzátehetjük, hogy Decsi strasbourgi doktori témavezetője, Hawenreuter professzor is összeállított egy szólásgyüjteményt (JLH).

Itt megemlíthetjük, hogy Dankanits Ádám vizsgálatai szerint Erdélyben a 16. században a külföldi szerzők népszerüségi listája a következő volt: Melanchthon, Erasmus, Cicero (DÁ-1) A számára hozzáférhetö könyvtárakban az Apophtegmatum Libri, az Epitome Adagiorum és a Chiliades Adagiorum 50 kötetét találta meg (DÁ-2). - Egy kis Erasmus-szólásgyüjtemény 1541-ben Brassóban is megjelent (EEp).

Erasmus szólásait ezresekre (chilias) osztja, ezeken belül vannak a százasok (centuria), s a százasokon belül sorszámozza az adatokat. A kötet más szerzőktől származó anyagában egyszerü sorszámozás van.

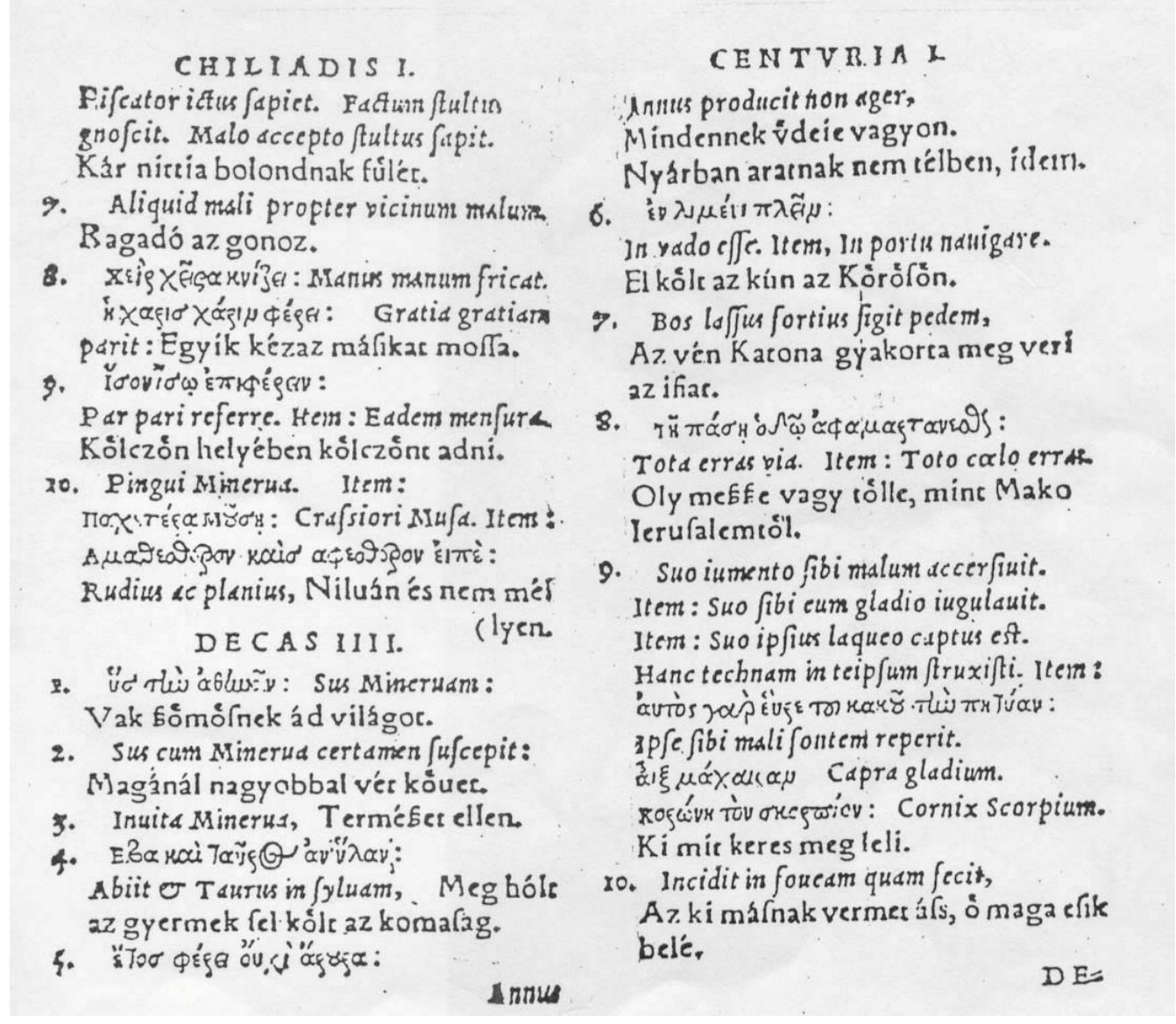

Az Adagiorum két oldala 


\section{Az Adagiorum szerkezete}

Decsi annyiban finomítja Erasmus rendszerét, hogy a százasokat (centuria) tízesekre (decas) osztja s csak ezen belül sorszámoz. Decsi válogat a mintaként szolgáló kötet anyagából, például a BD 3.7.9.4 (az első szám a chilias, azaz ezres, a második a centuria, a százas, a harmadik a decas, a tízes, a negyedik a decason belüli sorszám) megfelel az Erasmus 3.9.69nek (az első szám a chilias, a második a centuria, a harmadik a centurián belüli sorszám), a rákövetkezö 3.7.9.5 viszont már az Erasmus 3.9.100 megfelelője, tehát itt 30 Erasmus-tétel maradt ki. Hasonlóan a BD 5.1.7.7. megfelel a Gilbertus Cognatus 238-nak, a következö 5.1.7.8. viszont már a 248-nak, tehát itt kilenc Gilbertus Cognatus-tételt hagyott ki. Máskor viszont több Erasmus-tételt összevon, ilyenkor egy magyar adatnak több latin megfelelöje van. Az 1.3.7.10-ben egy görög mellett 26 latin adatot, az 1.5.6.7-ben két görög mellett 5 latin adatot találunk. A görög szöveget gyakran kiemeli a latin elé, olykor kissé megváltoztatja a latin szöveget, s gyakran nem Erasmus címsorát, hanem a magyarázat valamelyik mondatát emeli ki és teszi címsorrá. Erasmus latin magyarázatait és a klasszikus szerzőkre, pl. Horatiusra, Vergiliusra való hivatkozásokat elhagyja.

Röviden azt mondhatjuk, hogy a címsorokat tekintve Decsi 1.1.1.1-3.7.10.10, 4.1.1.14.10.9.5, 5.7.8.7-5.8.1.10. tételei Erasmustól, a 3.8.1.1-3.10.3.2. és a 4.10.10.4-4.10.10.10. tételek Hadrianus Iuniustól, a 3.10.3.3-3.10.6.8. Brassicanustól, az 5.1.1.1-5.6.3.1. Gilbertus Cognatustól, a többi más szerzőktől származik.

A latin-görög - gyakran csak latin, olykor csak görög - címsort a legtöbbször nem a fordítás, hanem a magyar megfelelő követi. Például az 5.3.2.6. tételben a latin: In idem flumen bis non descendimus-t (Ugyanabba a folyóba nem lépünk be kétszer.) az, hogy: „Az kinek egyßör az kása ßáiát meg égeti, tarlóiátis fúya”.

Előfordul a latin szöveg német megfelelőjének magyar fordítása is. Például az 1.3.3.2. tételben a Pecunia obediunt omnia (Mindenki enged a pénznek) magyar megfelelöjeként azt írja, hogy „Az ki nád között üll, ßintén ollyan sipot czinál, az minemüt akar”. Ez pontosan megfelel a Sebastian Franck 1541-ben kiadott német közmondásgyüjteménye (SF) 86v oldalán olvasható „Der in rorn sitzt, schneidt jm. Selbst pfeiffen wie er wil”-nek. Pontos német és nem latin megfelelöje van még például a következöknek is: „Gazda nélkül vet ßámot” (5.9.6.7.), „Az ki mézet akar enni, meg öllye elöb az méhet” (3.3.5.9.). (Megjegyzés: Régen a mézhez csak a méhek megölése utján lehetett hozzájutni.)

Tizenhat tételben két, egyben (3.4.7.7.) három, egyben (3.10.10.10.) négy magyar megfelelöt találunk. Néhány esetben a latin címsor feltehetően Decsi fordítása magyarból. Például a 2.5.3.3: Meße Buda sánta embernek - Procul Buda claudo, és 1.3.5.10: Nem kel az halottat az Szentegyháztól haza vinni - Non est funus ex coemiterio reducendum. Ezek a latin megfelelők nem találhatók meg Decsi forrásmunkájában.

Az Adagiorum 4795 tételben összesen 4827 magyar adatot tartalmaz. (A címben jelzett 5000től való eltérést kihagyások magyarázzák, pl. az első chiliasban csak 8 centuria van stb.) A magyar szövegek közül kb. ezer tekinthető szólásnak vagy közmondásnak. Magyar megfelelöként ugyanis sokszor csak egy szót, pl. Czintalankodni (1.2.4.8.), Czáczogó (1.4.2.1.), Állhatatlan (2.3.9.8.), Bolondság (2.3.9.10.), Boszorkány (5.1.9.10.), Homályosan (5.5.10.6), egy egyszerü kifejezést, pl. Haznos oruossag (1.2.6.9), Kegyetlen törvény (1.7.4.5.), Ostoba elme (2.2.10.4.), Meleg förödö (2.3.5.10.), Komoran nézni (3.4.10.4.), Haznos hazugság (4.10.6.2.), Erösen tanúlni (5.4.2.4.) stb., szólásnak vagy közmondásnak nem tekinthető egyszerü mondatot, pl. Ismerik ök egymást (2.5.5.10.), Veßedelmes dologban forgaz (4.10.8.7.), Az ió hirnek örülni (5.2.10.2.), Görög és Deák nyeluet tudni (5.9.6.1.) olvashatunk. 
Találunk még idézeteket, aforizmákat, gyakran a megfelelö latin vagy görög adat fordításait is. Például: Aequalitas non parit bellum - Az egyenlösęg nem támazt hadat (4.2.9.9.); Nullum violentum perpetuum - Nem állandó az valami erößackal léßen (5.2.10.1.); Sed quis custodiet custodes - Hát az örzökre ki vigyáz (5.1.6.5.); Mortuus rursus id eris quod prius - Föld vóltál, s vgyan földé kel lenned (5.1.7.6.) stb.

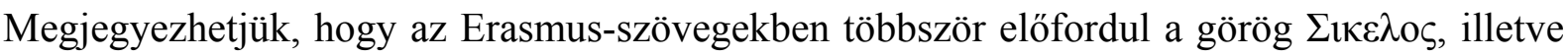
a latin Siculus szó, amely ott Szicília nem görög öslakosait jelenti. Decsi ezekhez a tételekhez az erdélyi székelyekre vonatkozó megfelelőt ír, pl. a „Siculus emphacisat” (2.4.10.4.) azzal egyenértékü, hogy: „No, mind fel veßi az ßékely, valami egy tetünél iob.” Többször találkozunk a ,Székely fortély” kifejezéssel is. (P1. 1.8.2.2, 2.3.5.5. stb.)

\section{Az Adagiorum szólásainak, közmondásainak utóélete}

Szenci Molnár Albert (1574-1634) Drezda és Heidelberg mellett - Decsihez hasonlóan - tanult Wittenbergben és Strasbourgban is, ahol szintén Hawenreuter professzor tanítványa volt. Naplója szerint 1592. június 18-án találkozott is Decsivel.

Szenci Molnár Albert - néhány 17. századi adattal kiegészítve - az Adagiorumnak kb. 400 közismert közmondását (usitatiora proverbia) felvette magyar-latin szótárának hanaui (1611) és heidelbergi kiadásába (1621), s ennek alapján ezek bekerültek a frankfurti (1644) és nürnbergi (1708) kiadásba (SzM-2-5) és a Pápai Páriz Ferenc-Bod Péter-szótárakba is $(1767,1782)$ (PPB).

Szenci Molnár Albert tehát válogatott Decsi anyagából, és néhány esetben változtatott is egyes szövegeken. Például Decsinél azt olvassuk: „Szemérem az futás, de haznos”(1.8.3.4.), Szenci Molnár Albert viszont már azt írja: „Szégyen a futás, de hasznos” (SzM-2.257/1., SzM-3.290/2., SzM-4.290/2).

Az Országos Széchényi Könyvtárban található egy 17. századi, erdélyi, ismeretlen protestáns szerző által írt Fasciculus Vocabulorum, Sententiarum et Adagiorum (FV) címü kézirat. Ennek első részében (a 73. folióig) Szenci Molnár Albert magyar-latin szótárának 1621-es (vagy a vele szövegében azonos 1644-es) kiadásából vett adatok olvashatók a latin megfelelőkkel együtt, a végén viszont már Decsi gyüjteménye volt a forrás. A FV szerzője válogat ebből az anyagból, s egyes tételeket meg is változtat. Helyesírásában a $c z$-t következetesen $t s$-re javítja.

Baranyai Decsi jó néhány közmondását megtaláljuk a kb. 1678-ban írt Actio Curiosa címü közmondás-színjátékben (AC) és - föleg Szenci Molnár Albert szótárai alapján - 18. és 19. századi tankönyvekben, mint pl. a Syntaxis Ornata-ban (SO) (1745-ös és későbbi kiadások), az Universae Phraseologiae Corpus-ban (1750, 1775) (UP), Cselkó István (CsI) és Verseghy Ferenc (VF) tankönyveiben. Kétségtelen, hogy a szájhagyomány mellett ezek a nyomtatott közlések is jelentősen hozzájárulhattak Decsi közmondásainak elterjedéséhez.

Részben a Szenci Molnár Albert-szótárak alapján Decsi számos közmondása került bele a második magyar közmondásgyüjteménybe, Kis-Viczay Péter kassai evangélikus lelkész Selectiora Adagia Latino-Hungarica in gratiam et usum Scholasticae juventutis címü kötetébe (KV). Ezt a Bártfai Nyomda adta ki Kassán 1713-ban. Kis-Viczay - Szenci Molnártól eltérően nem említi, hogy forrásul használta Decsi anyagát.

Baranyai Decsi és Kis-Viczay gyüjteményét először Ballagi Mór hasonlította össze 1883-ban (BM). A Decsi-gyüjteménnyel Tolnai Vilmos is foglalkozott (TV-1), s összefoglaló ismertetést találunk O. Nagy Gábor posztumusz magyar frazeológiatörténeti munkájában is. (ON). 


\section{Decsi szólásai és közmondásai a 20. században}

Az Adagiorumban található közmondásokat és szólásokat több szempont szerint osztályozhatjuk. Az egyik ilyen kiválasztási elv lehet azok mai ismertsége. Ennek alapján megkülönböztethetünk ma is közismerteket, olyanokat, amelyek ma már csak a magyar nyelvterület egy vagy néhány részén ismertek (regionális adatok) s végül mára már feledésbe merülteket.

\section{Ma is közismert, 400 éves közmondások, szólások (az esetleg zárójelben található évszám azt jelenti, hogy mai ismereteink szerint az adat 1598 előtt már akkor elöfordult):}

Kücziny az bòrs, de erös. 3.8.8.8. - Az Christus koporsoiát sem örzik heiában. 3.6.10.4. 1611ben már: ... örizték ingyen. (SzM-2.32/1) - Te sem vagy iob az Déákné váznánál. (1592) 3.4.4.3, 5.7.5.2. - Nagy fába vágtad az feißét. (1575) 5.4.10.4. stb. - Szemérem ( $m a$ : szégyen) az futás de haznos. (1589) 1.8.3.4. - Ember kel az gátra. 4.10.8.5. - Gazda nélkül vet ßámot. (1570) 5.9.6.7. - Ió vólnál halálnak. 4.5.1.1. - Olczó húsnak hig az leue. 2.8.4.7, 2.8.10.6, 4.3.3.10. - Az igaz mõdás bé töri embernek feiét. (1558) 2.9.3.5. - Lassan iáry, $\mathrm{s}$ hamaráb el iutz (vagy: hamaréb el érz). (1515-1540) 1.7.1.4, 2.1.1.1. - Ió töt helyébe iót ne váry. (15661536) 2.2.2.8, 2.5.8.3, 2.5.9.6, 4.6.2.8. - Az ketske sem meñe az vasárra, de czapiák hátúl. 3.8.6.5. - Semmit nem hoz az az konyhára. 3.2.9.6. - Köz lónak turos (azaz: feltúrt, sebes) az háta. 4.7.3.7. - Sok lúd diznót gyöz. 1.4.2.8, 3.7.7.6, 4.6.2.4, 5.4.8.9. - Oly meßße tölle, mint Mako Ierusalemtöl. 1.2.2.7, 3.4.3.3. - Az minemü mosdót te énnékem tartaz, énis ollyan kendöt te néked. 5.10.2.3, 3.9.4.2 (var.). - Nem akarásnak nyögés (az) vége. 2.5.1.5, 5.10.4.4. - Ió pap hóltig tanúl. 1.6.8.3, 5.5.3.8. - Iob mà egy veréb, hogy nem hólnap egy túzok. 5.1.2.5. - Sák meg lelte fól(t)iát. (1558) 1.4.5.1, 1.8.6.5, 4.9.3.7.

\section{Ma is közismert s egyúttal Európa több (zárójelben feltüntetett számú) nyelvében megtalálható közmondások:}

Aiándék lónak nem kel à fogát nézni. (48) 4.4.9.6. (marhának: 4.1.2.3.) - Az mely Ebet bottal haitnak az Nyúl vtán, soha az nyúlat meg nem fogia. (10) 1.6.1.8, 2.5.5.4, 4.1.3.5. (Szenci Molnár Albert 1611: Valamelly ebet botval haytnac az nyúl után nem fogja az meg. - 1623: Bethlen Gábor levele Károlyi Mihályhoz, Kolozsvár 1623. aug.16.: „leszen elegendö hadam nekem s talám igen sok is leszen, ha arra kél a dolog, tudom, hogy az mely ebet bottal üznek az nyúl után, meg nem fogja.”) - Nem hallik eb vgatás az menyorßágban. (10) 1.3.9.2, 5.3.9.10. - Czak ßörit veti el à farkas, nem terméßetit. (45) 3.3.2.2. - Talám azt várod, hogy sült galamb mennyen ßaiadba. (1566) (30) 5.5.2.3. - Egyík kéz az másikat mossa. (1582) (47) 1.1.3.8. - Az ßálkát más ember ßömében meg látod, az gerendát penig az magadéban nem látod. (1580-1582) (47) 1.5.5.2. - Czak addîg nyuitozzál, az mîg az lepel ér. (42) 2.5.3.7, 4.4.8.3. - Hituán madár az, az ki az ö maga fézkét meg rútittia. (28) 4.2.4.3. - Minem mind iauadat akaria az, az ki reiád mosolyodik. (6) 5.1.8.6. - Az ökör vgyan ökör, ha ßinte Béczbe haitiákis. (36) 2.8.7.2. - Szeget ßeguel ütni. (Szeget ßeggel kel ütni.) (21) (1536) 1.1.8.3. (5.3.7.3.) - Két ßöm mindenkor többet lát egynél. (48) 3.1.6.1. - Nem ió tüzet olaiual óltani. (38) 3.8.4.7. - Hiuatlan vendégnek aytó meget helye. (44) 1.2.5.3. - Nem arúlok ám én sákban matskát. (38) (1570-1571) 5.4.7.8.

Megjegyzés. Az Európában 28-54 nyelvben megtalálható közmondások, szólások: PGy-4, 600 magyar-észt-német-angol-finn-latin-cseremisz-zürjén adat: PGy-1. 


\section{Közismert és a szomszédos szláv nyelvekben is megtalálható közmondások:}

Az sok Bába közöt à gyermekis el ßokot vezni. 2.6.9.2. (belorusz, cseh, lengyel, lett, litván, orosz, szerb, szlovák, ukrán megfelelője ismert). - Ne hány borsót az falra. (1589) 3.1.6.4, 4.7.4.6, 4.9.6.4. (Ismert a cseh, lengyel, orosz, szlovák, ukrán nyelvben.) - Némának annya sem ért ßauát (1589: Néma gyermeknek..., 1606: Néma gyermeknek... Péchy Simon levele az udvarhelyszékieknek) 2.1.3.4. (albán, bolgár, cseh, lengyel, orosz, román, szerb, szlovák, szlovén, ukrán megfelelöje ismert).

Megjegyzés: A magyar közmondások nemzetközi és kelet-európai rokonsága: PGy-2, PGy-3.

\section{A ma már nem közismert, de a magyar nyelvterület egyes régióiban megtalálható közmondások: $(\mathrm{E}=$ Erdély, $\mathrm{Dsz}=$ Drávaszög, $\mathrm{SzM}=$ Szenci Molnár Albert szótára. 1611):}

Álom s esös üdö. (Bizonytalan dolog.) SzM, E, 5.8.4.8. - Nem fog (az) rosda (az) aranyon. SzM, E, Dsz, 2.6.2.3. - Vay ki hituán kereset az arúlkodás. SzM, E, Dsz, 2.9.10.3. - Bagolyis biro házában. SzM: barlangjában. E is, 4.4.1.3. - Nyert benne mint Bertók az czikban. SzM, E is. 4.10.10.9. - Bolondnak fa pénz ió, ha el veztiis ne bánkódgyék vtánna. SzM, E, 1.1.7.10. Nem minden botból léßen borotva. SzM, E is, 2.5.3.8. - Meße Buda sánta embernek. SzM (ebnek) E. (1838: Messze sánta ebnek Buda. - br. Jósika Jánosné levele fiához, Samuhoz, Csákigorbó. SzTA-2.529/1). - Oly kevély, mint ha öué volna az dió fáig. SzM, 2.8.2.6. Nem illik diznó orrába az arany peretz. SzM, E, DSz, 1.3.7.5. - Diznóra gyömbért ne veztegess. (1565) SzM, E is, 1.8.10.2. - Az ki én magamat ßeret, ebemetis ßereti. E nem, 5.8.3.9. - Két ház ebe. E nem, 3.9.2.3. - Még az ebnek sem ió az elsö fia. SzM, E is, 2.2.3.9, 5.1.2.3. - Hires eperre nem kel kosárual menni. SzM, Örség, Székelyföld (albán, bolgár, görög, orosz, szlovén, szerb, török megfelelöi ismertek). 1.7.2.10. - Czak Börit veti el farkas, nem terméßetit. (Suetonius: Vulpes pilum mutat, non mores.) SzM nincs, KV-549, csak Erdélyben ismert (50 adat, Háromszék, Magyaró, Magyarózd, Maros-Torda, Szatmár, Szovát, északi csángó). - Farkast emlegetnek, kert meget kullog. SzM, több vidéken ismert, 2.7.9.3., 4.5.2.3. - Vay ki erös mint az etzet. E is, 3.1.8.6. (1614: Az én szententiám szerint bezzeg erös, mint az oláh etzet az te bizonyságod. Pázmány Péter, PPÖ-5.87.) - Minden ember az ö maga fazeka mellé ßît. SzM, E (Magyaró, Magyarózd, Nagybánya, északi csángó). 1.1.9.2, 1.3.3.3. - Az gazdagnakis kettö orra lika, mint az ßegény ember diznaiának. SzM, E, 2.1.1.7. - Soha nincz oly nagy hoßßu hágó, kinek leitöie ninczen. - E (Háromszék, Magyaró, északi csángó). - Addîg hámcz az hárs fát, mîg hámlik. (1575/1495) SzM, E (Magyaró, Székelyföld) 3.4.1.10, 4.3.10.9. - Nem kel az halottat az Szentegyháztól haza vinni. - E is. 1.3.5.10, 2.6.8.5. (1598 után elöször 1862-ben jelenik meg.) - Az ki Nyárban nem gyüjt, Télben agebül bánkodik. SzM, E is, 5.8.8.5. - Még üdeién meg látzik az mely teyböl ió túro léßen. SzM, E is, 4.2.1.10. stb.

Megjegyzés: Az erdélyi és partiumi gyüjtések közül föleg a következőket vettük alapul: Bura László (BL) szatmári, Horváth István (HI) magyarózdi, Jakab Rozália (JR) farkaslakai, Konsza Samu (KS) háromszéki, Kovács Ferenc (KvF) kisiratosi, Kriza János (KJV) székelyföldi, Molnár Béla (MB) sóváradi, Ősz János (ÖJ) kibédi, Sándor Mihályné Nagy Gabriella (SNG) székelyföldi, Seres András (SAn) barcasági, Tamás Irén (TI) szováti, Vöő Gabriella (VG-1, VG-2) erdélyi, Wychmann Yrjö (WY) északi csángó és Zsigmond József $(Z s J)$ magyarói gyűjtése. Az „Addig hántsd a hársfát, míg hámlik” részletesebb vizsgálata: PGy-5.

Látható, hogy az adatok jelentős része Erdélyben vagy Erdélyben és a drávaszögi gyüjtésben (LK) maradt fenn. 
5. Mára már feledésbe merültek. Ezekre vonatkozóan 20. századi regionális adatok sem bukkantak fel az eddigi vizsgálatokban, viszont általában Szenci Molnár Albert 1611-ben a használatos proverbiumok közé sorolta őket. Ennek hiányában Kis-Viczay Péter (KV) 1713ból származó adatát adjuk meg. (A stb. azt jelzi, hogy ez az adat a Decsi-gyüjteményben a feltüntetett mellett még többször is előfordul.)

Nem álmot hüuelyezek én, hanem igazat mondok. 2.10.9.2. SzM-2.-9/1. - Egy babot nem adnék raita. 4.6.5.4, SzM-2.15/1. - Sokat kér az beteg, de nem adgya az egésséges. 2.5.9.4, SzM-2.249/1. - Igen illik mint az bot az tegezbe. (1570) 1.7.3.4. stb., KV-34. - Minden botnak az végén az feie. (=Végén csattan az ostor.) 1.3.10.8. + 5 adat, SzM-2.29/1. - Eßes diznó, mely gyüköret ránta. 3.6.1.3, SzM-2.69/1. - Fakotis vonnyák, de fakois vonnya. (1566) 2.2.8.4, SzM-2.71/2. - Kü ßöktek az felsö várból. (= Elment az esze.) (1592) 1.8.7.3. stb., SzM-2.149/1. - Czak gallérais alig marat. 3.10.5.3, SzM-2.90/2. - Ha nincz irod és ßelentzéd, miért teßed magad borbéllyá. 4.3.8.2. (1556: Nádasdy Tamás levele: A töröknek sem ire, sem szelentzéie. - 1584: Báthory István levele: Sem irönk, sem szelentzénk.) - Régi irás, el kopot. 1.4.1.5. stb., SzM-2.236/1. - Az kinek az kása meg égeti az ßaiát mêg az tarlóiátis fuia. 2.2.9.9. (2.3.6.3, 5.3.2.6.), SzM-3.148/2. (Részletesebben lásd: PGy-6.) - Kenyér, sait, két tál étek. 4.5.5.3, KV-464. - Késö sütue. (= Eső után köpönyeg.) (1589) 1.1.3.5. stb. SzM2.139/2. - Igen gondol király vduarbiróual. (1575) 1.7.7.4. stb. SzM-2.147/2: Nem fél király udvarbirótól. - Kötve hüd komádat (1566) 2.1.7.7, SzM-2.155/2. - Kopár helyön keresködöl. 1.3.8.4. stb., SzM-2.158/2. - Malomban hegedülni. 2.9.9.2, SzM-2.173/2. - Meg sem fogtad saddig mellyezted. (= Elöre iszol a medve börére.) 1.5.10.8, SzM-2.196/2. - Bezzeg nömös vólt ám öis, de mind el hordották az fazék gyártók. 3.8.2.5, SzM-2.208/1: ...de elhordtác az fazekasoc à földét. - Kereztül tenni az Orbán süuegét. (= Felönteni a garatra.) SzM-2.220/2: Feltenni ... - Igyál ökör, tó víz. 4.6.1.6, SzM-2.124/1. - Öis sok pénteket ért ugyan immár. (= Idős ember.) 4.7.2.5. stb., SzM-2.227/1: Elérte à soc péntek. - Pénz emberség, ruha tiztesség. (1515-1540) 2.4.7.9. SzM-2.227/1. - Pokolbanis esik egyßör egy Innep. 5.8.4.4, SzM2.230/1. - Igen tudgya ö, ha töke auagy túros étek. 1.3.7.3, 3.2.3.8, SzM-2.280/2. - Egy tiukmony sültîg meg lenne az. 3.6.7.1., SzM-2.278/1 (Hermányi Dienes Péter székelyföldi, erdővidéki esperes [1707-1741] azt írta egyszer a hozzá tartozó lelkészeknek, hogy „a harangozás felettébb hosszú ne légyen, hanem legtovább, míg egy tyúkmony megsülne”. BkJ1.30. - (tyúkmony = tyúktojás). - Rosz váras az, az kinek óráiát hituánúl iártattiák. 5.3.1.5., SzM-2.220/2: Az óra jártatásábol is_megitilheted a várost.

\section{Ami hiányzik az Adagiorumból}

Decsi János gyüjteménye a legtöbb régi magyar közmondást tartalmazza, s nagy többségükre vonatkozóan ez a legrégebbi feljegyzés. Néhány valóban „hiányzik”, ilyenek például az először 1575-böl ismert: „Akármind perseld az ebet nem lészen szalanna benne”, amely ma „Kutyából nem lesz szalonna” megfogalmazásban közismert, Vöő Gabriellának 141 hivatkozása van rá (VG-1.168/514), „Holló a hollónak nem vájja ki a szemét” (1584-ből), „Aki korpa közé keveredik, megeszik a disznók” (1577-ből), „Kerülgeti, mint macska a forró kását (1569-ből). Egy kevésbé ismert példa 1581-ből: „Az ellőtt nyilat nehéz visszahozni”, amelyre egy erdélyi adat van (VG-1.197/25) és öt török nyelvben ismert (BU-1933).

Más esetekben azért nem találunk meg egy régi közmondást, mert az csak később jelent meg a magyar nyelvben. Például a „Nem mind arany, ami fénylik” vagy az „A kákán is csomót keres" első magyar feljegyzése későbbi, 1613-ból való.

Néhány esetben a Decsi-gyüjteményben megtaláljuk a „hiányzó” közmondás pontos latin megfelelőjét. Ezek magyar fordításban ma közismert közmondások, akkor azonban ilyen 
formában még ismeretlenek voltak. Ilyenkor a fordítás helyett Decsi körülírást ad. Például az 1.6.10.10. tételben a „Bis dat, qui cito dat” magyar megfelelője Decsinél nem a „Kétszer ad, aki gyorsan ad”, hanem: „Ha valami iót akarz tenni valakiuel, hamar tegyed”. Hasonlóan a 3.4.6.8. tételben a „Saxum volutum non obducitur musco” magyar megfelelőjeként nem a „Gördülö kövön nem nö moha” fordítást olvassuk, hanem azt, hogy „Nehezen gazdagodik az meg, az ki gyakran helyet cserél”, és azt is, hogy „Nehezen léßen ió Déák, az ki sok külömb külömb Scholákot válogat”. A „Nemo propheta acceptus est in patria sua” (Senki sem próféta a saját hazájában) magyar megfelelője: „Egy fö ember sem böczültetik hazájába (5.5.5.7.). A „Piscis primum a capite foetet” (Fejétől büzlik a hal) megfelelöje pedig „A hól az fö meg vez, az tagokis meg veznek ott" (4.2.9.10.). Az említett latin mondatok magyar fordításai csak később váltak közmondássá a magyar nyelvben.

\section{Néhány megjegyzés az Adagiorum nyelvéről}

A mássalhangzóval kezdődő főnevek előtti határozott névelő nem „a”, hanem a legtöbbször „az”, pl. „Egy az ßoba az kementzéuel” (1.1.1.1.), de pl. mind „a”, mind „az” előfordul a következőben: Szeretné à haznot, de fút az munkától (4.1.3.3.).

A -val, -vel rag hasonulása gyakran - mint a moldvai csángók nyelvében - nem történik meg. Például azt olvassuk, hogy „Sem Istenvel, sem embervel nem gondolni” (5.9.5.9.). Előfordul azonban ugyanarra a szóra vonatkozóan is, hogy az egyik esetben hasonul, a másikban viszont nem hasonul a -val, -vel. Például: beßédvel (4.1.8.5, 4.7.1.7.), de beßéddel (4.2.3.9, 4.7.9.6.).

A nyáron, télen helyett azt olvassuk, hogy nyárban, télben. Pl. „Az ki Nyárban nem gyüjt, Télben agebül bánkodik" (5.8.8.4b.).

Egyes szavakban a „,szokásos” $i$ helyett $\ddot{u}$ hang van, pl. üdö, hüß, kütsin/küczin, ßüv, küuül, tü stb., másokban pedig $e$ helyett $\ddot{o}$, pl. böczület, czeleködni, egyßör, élös, emléközik, étök, györtya, ió töt, nömös, önyves, ßöm, ßörzö, veröm stb. Ezek a nyelvjárási jellegzetességek eltünnek Szenci Molnár Albert szótárában és a későbbi előfordulásokban.

Több, mára már feledésbe merült szóval is találkozunk. Ilyenek pl. a mony (tojás) (4.1.1.5.), eh (máj) $(2.9 .2 .10,5.1 .1 .1,5.6 .8 .2,5.8 .1 .5,5.8 .7 .6$.$) , turba (kulccsal zárható pénzeszacskó,$ török jövevényszó a magyarban) (2.9.5.4.), közköpülködik (fondorkodik) (2.2.10.9.). A gyakran előforduló minem szó jelentése egyszerüen nem, pl. „Minem hallik ßamár riuás menyorßágban (5.2.6.5.). Az elromlott Decsinél el roßúla (5.6.5.9.), a mai leselkedni pedig lesesködni (5.4.3.10.). A város helyett mindig azt találjuk, hogy váras (3.3.10.3, 4.10.4.5, 5.3.1.5.), ugyanúgy, mint Tinódinál.

Ha egy mai közmondásban kutya van, akkor a Decsinél található megfelelőjében biztosan ebet találunk, pl. „Az mely Ebet botual haitnak az Nyúl után, soha az nyúlat meg nem fogia” (1.5.1.8.). Akkor a kutya jelentése „kis eb” volt. A hitvány jelentése: rossz, a jámboré emberekre vonatkozóan - jó (2.5.7.7, 5.9.5.10. stb.). Iámborodni = megjavulni (2.9.1.10.). A ma csak emberekre vonatkozó $k i$ vonatkozhatott állatokra, pl. „Nincz oly agh róka, kinek böre az czáuában nem kerül” (2.4.10.5.), tárgyakra, pl. „Nincz oly rakot ßekér, Kire egy vella ßéna fel nem fęr” (4.8.10.4.) vagy akár egy országra is: „Szegény orßág kit ßamár hátõ dúlnak” (1.5.1.2.).

Az is mindig egybe van írva a megelőző szóval, pl. bagolyis (1.5.10.3.), másrészt az igekötőt mindig külön írták, pl. „Ki ßöktek az felsö várból” (4.6.3.5.). 
Az $l$ hangot megelőző magánhangzó mindig hosszú, pl. hóltig tanúl (1.6.8.3.), hólnap (2.9.1.5.), amint arra már Török Gábor rámutatott (TG). A melléknevek középfokában magánhangzó után -bb helyett mindig -b van, pl. erösb (5.6.5.7.), eßesb (5.8.3.2.), igazb (5.2.7.5.), iámborb (4138.), iob (2.9.1.5.), keduesb (4.3.1.7.), vakmeröb (4.5.2.7.).

Az Adagiorum általában a 16. századi protestáns helyesírást $(\mathrm{KI})$ használja, cz $=\mathrm{cs}$ (mint a lengyelben), $\mathrm{tz}=\mathrm{c}, \mathrm{s}=\mathrm{zs}$ (egyes esetekben), pl. sak (1.4.5.1.), darast (1.8.9.6.). Elöfordul a ts $=$ cs is, pl. a legtöbbször ezt találjuk a matska szóban, bár előfordul maczka is. Az $s z$ hang jelölése sz, $\beta$, vagy z, pl. Szömét (2.9.2.5.), alußik (2.9.2.2.), gonoz (2.9.2.3.), ezköz (2.3.3.6.).

\section{Tervek, problémák}

Tervbe vettük a Decsi-kötet szólás- és közmondás-anyagának feldolgozását az előzmények és az adatok 1598 utáni előfordulásainak részletes felsorolásával, ide értve a regionális gyüjtéseket is. Eddig már több száz adat feldolgozása kéziratban van, egy példát függelékben közlünk.

Az Adagiorum vizsgálata során több olyan kérdés merült fel, amelyekre eddig nem sikerült választ találni. „Több szem többet lát” alapon talán valaki rátalál a megoldásra. Néhány megválaszolatlan kérdés pl.:

Ki volt Varkucz György? Decsi ezt a munkáját neki mint támogatójának ajánlja: Magnifico Domino Domino Georgio Varkucz. Róla eddig semmit sem sikerült megtudni.

Mit jelent a maragaroggia? - Eamus Athenas - El mégyé másßoris maragaroggiába (4.5.8.7.). Későbbi előfordulásai: SzM-2.174/1, PPB-1.218/2, KV-135. Erdélyi Jánosnál (1851): Maradgarodgyába menni (valaki jobb sorsát elhagyva olyanba jutott, ahonnan visszakívánkozik). EJ-5394.

Mi a tzaponkurt ? - Dicas tria de curia. - Mondgy egy tzaponkurtot (3.3.1.1.).

Ki volt Lukáts Fábián? Tonitru imbrem antecedit. - Meg üti Lukáts Fábiánt (5.1.5.1.).

Ki volt Nagy Urbán ? - Aries cornibus lasciuiens. - Nagy Vrbán elég látor (3.6.5.8.).

Ki volt Gál bíró ? - Saluetote volucripedum soboles equorum. - Isten gyonapot Gál biro (5.9.9.9, 3.4.7.7. var.).

Ki volt „huzheiános”? - A $\lambda \imath \imath$ pıos. - Aliterius. - Azis el venne ám az huzheiánost (4.1.8.2.). 


\section{Irodalom}

AC Actio Curiosa. Gaude, avagy Csernél Istvánnak beszélgetése. (kb. 1678) - Kardos Tibor (szerk.): Régi magyar drámai emlékek. Akadémiai Kiadó, Bp. 1960. 2. kötet, 354-396.

$B D$ Baranyai Decsi János: Adagiorvm Graecolatinovngaricorvm chiliades quinque, ex Des. Erasmo, Hadriano Iunio, Ioanne Alexandro (Brassicano), Cognato Gilberto et alijs optimis quibusque paroemiographis excerptae, ac Vngaricis prouerbiis, quoad eius fieri potuit, translatae, studio et opera succisiua Ioannis Decii Baronij. - Excudebat Iacobus Klöß, Bartphae 1598. - (18) + (1-127) + 128-424 + (2) old. $12^{\circ}$. (RMNy-815)

BkJ Benkő József (1740-1814): Transsilvania specialis. Erdély földje és népe. I-II. kötet. (Ford. Szabó György). Kriterion Könyvkiadó, Bukarest-Kolozsvár (1999) 653 + 845 old.

BL Bura László: Szatmári szólások és közmondások. (Magyar Csoportnyelvi Dolgozatok 35.) ELTE Magyar Nyelvtörténeti és Nyelvjárási Tanszéke, Budapest 1987. 147 old. (2312 adat)

BM Ballagi Mór: Baronyai Decsi János és Kis-Viczay Péter közmondásai. Értekezések a Nyelv- és Széptudományok köréböl. 10. kötet, 5. füzet, 15. (1882)

$B U$ Bläsing, Uwe: Tschuwaschische Sprichwörter und sprichwörtliche Redensarten. Harrassowitz Verlag, Wiesbaden 1994. 849. (4396 tétel)

CsI Cselkó István: Magyar közmondások. = Cselkó István: Válogatott darabok, minden korú jeles magyar irókból. Az ifjúság hasznára. Belnay özvegy és örökösei, Posonyban, 1817. 123-154. old.

DA-1 Dankanits, Ádám: Erasmus erdélyi olvasói. Nyelv- és Irodalomtudományi Közlemények 11. 125-131. (1967)

DA-2 Dankanits Ádám: 16. századi olvasmányok (Erdélyben). Kriterion, Bukarest, 1974.

EEp Erasmus Roterdamus: Epitome adagiorvm Graecorvm \& Latinorum iuxta seriem Alphabeti. Ex Chiliadibus Eras. Roterodami. (Honter, Corona - Brassó) 1541. 56 fol. (RMNy-43.)

EJ Erdélyi János: Magyar közmondások könyve. Kozma Vazul, Pest 1851

ErAd Erasmus, Desiderus: Des. Erasmi Roterodami Adagiorvm Chiliades qvatvor cvm sesqvicentvria, ex postrema authoris recognitione... Ex Officina Episcopiana, per Eusebium Episcopum et Nicolai Fr. haeredes, Basileae MDLXXIIII (1574), (116) $852+647+(86)$ old., $2^{\circ}$ Erasmus 852 oldalas szövege (1.1.11 - 5.2.51: Typographus lectori (1-96. hasáb), Adagiorum Appendix ex Erasmi Chiliadibus ad studiosum commoditatem excerpta (97-109. 1-160. sorszámok), Hadrianus Iunius (109-288. 840 tétel), Johannes Alexander Brassicanus (288308. 146 tétel), Johannes Ulpius (308-316. 127 tétel), Gilbert Cousin (Cognatus) (316-602. 1810 tétel), Ludovicus Caelius Rhodiginus (602-606. 53 tétel), Polydorus Vergilius (606610. 60 tétel), Petrus Godofredus (610-613. 36 tétel), Charles de Bovelles (613-617. 47 tétel), Adrianus Turnebus etc. (617-620. 30 tétel), Gulielmus Gentius (620-624. 50 tétel), Specimen quoddam adagiorum quae ab Junio, Cantero et Giselino... collecta sunt... (625-632. 49 tétel), Adagia of Melchior Neipeius (632-647.) (OSzK)

FV Fasciculus Vocabulorum, Sententiarum et Adagiorum. 17. századi kézirat az Országos Széchényi Könyvtárban. (Duod. Hung. 51.)

HI Horváth István: Közmondások, szólások (Magyarózdon). = Horváth István: Magyarózdi toronyalja. Dacia, Kolozsvár 1971. 287-295. (Második, átdolgozott kiadás: Magyarózdi toronyalja. Írói falurajz egy erdélyi magyar faluról. Magyar Helikon, Budapest 1980. 338351.) 
JLH Hawenreuter, Johannes Ludwig: Adagia classica scholis Argentinensibus digesta. Excudebat Iacobus Rihelius (Argentorati) 1573. a + $302+(5)$ old.

JP Janus Pannonius - magyarországi humanisták. Szerk. Klaniczay Tibor. Magyar Remekírók sorozat, Szépirodalmi Kiadó, Bp. 1982. 1412 old.

$J R$ Jakab Rozália: Közmondások, szólások (Farkaslakán). = Jakab Rozália: „Nálunk a harangszó elszáll a határig." Népélet és néphagyomány Farkaslakán. Tamási Áron Alapítvány (Bp.) - Polis Könyvkiadó (Kolozsvár) 1998. 134-136. old.

KI Kniezsa István: A magyar helyesirás története. 2. kiadás. Tankönyvkiadó, Budapest 1959. 23.

KJV Kriza János: Vadrózsák. Székely népköltési gyüjtemény. 1. kötet. Stein János, Kolozsvártt 1863. (Reprint: Akadémiai Kiadó, Budapest 1987)

KS Konsza Samu: Közmondások, szólások (Háromszéken). = Konsza Samu: Háromszéki magyar népköltészet. Szerk. Faragó József. Állami Irodalmi és Müvészeti Kiadó, Marosvásárhely 1957. 485-501. 871-1475. tétel (605 adat)

$K V$ Kis-Viczay, Petrus: Selectiora Adagia Latino-Hungarica in gratiam \& usum Scholasticae juventutis collecta et in alphabeti seriem concinnata ... Studio \& vigilantia Petri Kis-Viczay p.n. Eccl. Aug. Conf. Cassov. Nat. Hung. Past. - Typis Civitatis, Bartphae (akkor Kassán!) 1713. 552 old.

$K v F$ Kovács Ferenc: Közmondások (Kisiratoson). = Kovács Ferenc: Iratosi kertek alatt. Kisiratosi népköltészet. Szerk. Faragó József. Állami Irodalmi és Mủvészeti Kiadó, Bukarest 1958. 213-220.

LK Lábadi Károly: Ahogy rakod tüzed. Drávaszögi magyar proverbiumok. Horvátországi Magyarok Szövetsége, Eszék 1986. 352 old. (2982 adat)

MB Molnár Béla: Sóváradi szólások és szóláshasonlatok. Müvelődés (Bukarest) 36. évf., 11. sz. 33-34. (1983. november)

ON O. Nagy Gábor: A magyar frazeológiai kutatások története. Szerk. Kovalovszky Miklós. Nyelvtudományi Értekezések 95. Akadémiai Kiadó, Bp. 1977. 15-21.

OK Olosz Katalin: Közmondások, szólások (Magyargyerőmonostoron). = Olosz Katalin: Magyargyerömonostori népköltészet. Irodalmi Könyvkiadó, Bukarest 1969. 237-238. 396468. sorszám (75 adat)

ŐJ Ösz János: Kibédi közmondások. Magyar Nyelvőr 30. kötet, 399-400. (1901)

PGy-1 Paczolay Gyula: Magyar, észt, német, finn, latin közmondások és szólások cseremisz és zürjén függelékkel. MTA-VEAB, Veszprém 1987. 300 old.

PGy-2 Paczolay Gyula: Magyar közmondások és szólások nemzetközi rokonsága. Acta Hungarica 4-5. évf., 36-51. (1993-1994)

PGy-3 Paczolay Gyula: Magyar közmondások és szólások kelet-európai rokonsága. Acta Hungarica 6. évf., 62-68. (1995)

PGy-4 Paczolay Gyula: European proverbs in 55 languages with equivalents in Arabic, Persian, Sanskrit, Chinese and Japanese. - Európai közmondások 55 nyelven, arab, perzsa, szanszkrit, kínai és japán megfelelőkkel. Veszprémi Nyomda RT. Veszprém 1997. 528 old.

PGy-5 Paczolay Gyula: Az első feljegyzett magyar és lengyel közmondás. Addig/Akkor hántsd a hársat/hársfát, amíg/amikor hámlik - Kiedy się łyka dra, wtenczas/wtedy je drzyj. Ethnica 2. évf., 1. szám, 1-4. (2000) 
PGy-6 Paczolay Gyula: Akinek a forró kása megégette a száját, az aludttejet is megfújja. Adatok egy közmondás történetéhez. Ethnica 3. évf., 1. sz. 7-9. (2001)

PPB Pápai Páriz Ferenc - Bod Péter: Dictionarium Hungarico-Latinum. Olim magna cura a clarissimo viro Alberto Molnár Szentziensi collectum, tandem revisum \& aliquot vocabularum, in Molnarino desideratum, millibus Latine redditis locupletatum, studio \& vigiliis Francisci Páriz Pápai, Medicinae Doctoris, \& in Alma Enyedina publici Professoris... Opera Petri Bod de F(elsö) Tsernáton, V.D. Ministri M(agyar) Igeniensis. Novae huic editioni nunc secundo solertia Typographi addita est Lingua Germanica. Sumptibus Martini Hochmeister Caes. Reg. Typographi \& Biblop. Cibinii (Nagyszeben) Anno MDCCLXVII (1767) $404+2$ old. (A Dictionarium Manuale Latino-Hungaricum... Proverbiis selectioribus interspersis... 2. része.) Változatlan kiadása 1782

PPÖ Pázmány Péter összes művei. (Magyar nyelvű művek.) 1-7. kötet. A Pázmány Péter Tudományegyetem Hittudományi Kara, Bp. 1894-1905

SAn Seres András: Közmondások-szólások (a Barcaságon). = Seres András: Barcasági magyar népköltészet és népszokások. Szerk. Keszeg Vilmos. Kriterion Könyvkiadó, Bukarest 1984. 313-318. 677-933. tétel (257 adat)

SF Franck, Sebastian: Sprichwörter, Schöne, Weise, Herzliche Clugreden und Hoffsprüch, Darinnen der alten und nachkommenen aller Nationen unnd Sprachen gröste vernunff unnd klugheyt. ... Beschriben ... Durch Sebastian Francken, Getruckt ... Bey Christian Egenolffen, Franckenfurt am Meyn 1541. 163 fol. + 211 fol.

SNG Sándor Mihályné Nagy Gabriella: Székely közmondások. (Magyar Csoportnyelvi Dolgozatok. 44.) ELTE Magyar Nyelvtörténeti és Nyelvjárási Tanszéke, MTA Nyelvtudományi Intézete, Bp. 1990. 48 old. (1081 adat)

SO Idiotismi Hungarici Adagiales, qui nisi circumlocutione aliqua hungarice reddi nequeunt. = Syntaxis Ornata, seu de Tribus Latinae linguae virtutibus, puritate, elegantia, copia. In Usum Mediae \& Supremae Grammaticae Classis studiosorum. Typis Academicis Societatis Jesu, Tyrnaviae (Nagyszombat) Anno 1745. 60-62. (Reprint: Nagyszombat 1748, 1754; Kolozsvár 1772; Buda 1792)

SzM Dictiones Ungaricae, summo studio collectae et Latine conversae, iuxtaque ordinem literarum prout scribi solent, digestae, nunc denuo diligenter emendatae, plurimus vocibus formulisque loquendi Latine redditis auctae: et usitatioribus Proverbiis Ungaricis, cum Latinis Adagiis aequipollentibus locupletatae, quae ad initialem vel praecipium Adagionis Ungaricae vocem facile inveniuntur. Auctore Alberto Molnar Szenciensi. Typis Thomae Villeriani, Hanoviae (Hanau), MDCXI (1611) 335 old. (A Lexicon Latino-GraecoHungaricum második része.) (RMNy-1012) (Bővített kiadás: SzM-3: Heidelberg 1621, 368 old. RMNy-2099. Változatlan utánnyomása: SzM-4. Frankfurt 1644. 368 old. RMNy-2099. Némettel bővített kiadás: SzM-5. Nürnberg 1708. 576 old.

SzTA Szabó T. Attila: Erdélyi magyar szótörténeti tár. I - IV. kötet. Kriterion Könyvkiadó; V-X. kötet: Kriterion Könyvkiadó-Akadémiai Kiadó, Bukarest-Bp. 1978-2000.

TI Tamás Irén: Népnyelvi hagyományok Szováton. Müvelődés (Bukarest) 33. évf., 9. szám, 33-35. (1979)

TG Török Gábor: Adalékok a liquidák nyújtó hatásának jelentkezéséhez. Magyar Nyelv 50. évf., 32-37. (1954)

TV-1 Tolnai Vilmos: Adalék a szóláshasonlatok, szólásmódok és közmondások elméletéhez. (Akadémiai székfoglaló 1909. március 22-én.) (A Magyar Nyelvtud. Társaság Kiadványai 12.) Bp. 1910. 23-41. 
TV-2 Tolnai Vilmos: Decsi János Adagiumainak forrása. Magyar Nyelv 7. évf., 223-224. (1911)

UP Universae phraseologiae Latinae corpus congestum a P. Francisco Wagner, Societatis Jesu Sacerdote, ...demum apud nos linguis Hungarica \& Slavica, locupletatum. Typis Academicis Societatis Jesu (Tyrnava - Nagyszombat) Anno MDCCL (1750), 1272 old. (Reprint: 1775)

VG-1 Vöő Gabriella: Igaz ember igazat szól. Közmondások a romániai magyar folklórból. Kriterion Kiadó, Buc. 1989. 316 old. (5662 közmondástípus, változatokkal)

VG-2 Vöő Gabriella: Szaván fogjuk. Erdélyi magyar szólások. Erdélyi Gondolat Könyvkiadó, Székelyudvarhely 1999. 372 old. (Reprint 2001-ben, zöld helyett sárga borítólappal, változatlan, 1999-es évszámmal.)

VK Viski Károly: Közmondások, szólások, hasonlatok (Tordán). = Viski Károly: A tordai nyelvjárás. (Nyelvészeti Füzetek 32.) Athenaeum, Bp. 1906. 37-39.

WY Wichmann, Yrjö: Sprichwörter, Phrasen (des moldauer Nordcsángódialektes). = Wichmann, Yrjö: Wörterbuch des ungarischen moldauer Nordcsángó und des hétfaluer Csángódialektes nebst grammatikalischen Aufzeichnungen und Texten aus dem Nordcsángódialekt. Szerk. Csüry Bálint és Artturi Kannisto. Lexica Societatis Fenno-Ugricae IV. Suomalais-Ugrilaisen Seura, Helsinki 1936. 201-211.

ZsJ Zsigmond József: Közmondások és szólások (Magyarón). = Zsigmond József - Palkó Attila: Magyaró néphagyományaiból. Szemelvények. Mentor Kiadó, Marosvásárhely 1996. 97-116.

\section{Függelék}

Igen tudgya ö, ha töke, auagy túros étek. (He well knows whether he/it is a pumpkin or a curdy meal.) Gr + Sus tubam audivit. BD-1.3.7.3. - Én nem tudhatom, ha töké, auagy túros étek. (I cannot know whether this is a pumpkin or a curdy meal.) - Carcini poemata. BD3.2.3.8.

Szenci Molnár Albert - 1611: Igen tudgya ö ha töke vagy túros étec. SzM-2.280/2. - 1621: SzM-3.317/1. - 1644: SzM-4.317/1. - 1708: SzM-5.519/1.

17. század -1606: Igön tuggya ha töke auagi turos étök. (Szárászi Ferenc 125/144). - 1609: Azt is tennen itéletedre hagyom, mit érdemellyen az Istentül, az ki azt sem tuggya, ha tök-é vagy turós étek a Helvéciai Confessió. (Pázmány Péter Alvinczy Péterhez) PPÖ-2.532. 1659: Ighen tudgya a Paule, tök-é vagy turós-étek (Czeglédi István: Redivivus Iaphetke. 154.) - 1674: (A lengyel királynak) ... az én személyemröl is irjon, mind azt sem tudja talán, tök vagyok-e vagy túrós étek. (Bánffy Dénes levele Teleki Mihálynak, 1674. okt. 15.) Magyar Nyelv 13, 24 (1917)

18. század - 1713: Azt sem tudgya, tök-é vagy túrós étek. Kis-Viczay 341. - Igen tudgya ö, ha töké vagy túrós étek. Kis-Viczay 500. - 1750: Nem nézi tök-e vagy turós étek. (Mindent elhisz.) UP-1183/1. - 1767: Igen tudja ö, ha tök-é vagy túrós étek. PPB-1.370/1 (= 1782: PPB-2.370/1). - 1780: Nagy határ pásztornak poltzra emeljétek, Holot azt sem tudja, tök vagy turos étek. (Nagy György: Konok pereskedök. Marosvásárhely). Protestáns iskoladrámák 718/1971-1972. - 1787: Igen tudod, tök e, vagy túrós étek. (Faludi Ferenc 224). - 1788: Igen tudgya ö, ha tök e', vagy túrós étek. (Máriaffy István 2.148/1). - 1789: Ha kérdik tőlök, hogy által-vető mit tesz Deákúl, tsak el-tátják a' szájokat, s' azt sem tudják, ha tök-é? vagy túrós étek. (Illei János: Tornyos Péter). Jezsuita iskoladrámák 1. 466/465-466. - 1790: Azt sem 
tudod, tök-e vagy túrós étek. (Noszkó Alajos 219/3). - 1794: Azt sem tudja, ha tök-é, vagy túrós étek. (Kovács Pál 51). - 1795: Igen tudja töké vagy turos étel. (Szent-Páli István 288/90b)

19. század - 1803: Tsak a' tököt sem tudod a' túrós étektöl meg-választani. (Nem értesz a' dologhoz.) (Baróti Szabó 442/33f). - Tsak a' tököt sem tudgya a' turós étektöl megválasztani. (Baróti Szabó 453/10). - 1804: Azt sem tudgya tök-é vagy túrós étel? (Szirmay Antal 118). - 1810/1820: Azt sem tudgya: tök-é? vagy túrós étel. (Dugonics 1.117). - 1815: Pirongatnálok az Szen(t) Irás Szavaibol, hogy az tálentumodat el ne ássad [...] de Te aszt sem tudod, hogy Tökk é vagy Turos Étek. (Kóród, gr. Kornis Gáspár levele fiához) SzTA-3-490/1. - kb. 1815: Tsak a' tököt sem tudja megválasztani a' túrós ételtől. (Kassai József 6.97). 1817: Igen tudod, tök-e, vagy túrós étek. (Cselkó István 138 = Faludi Ferenc). - 1822: Igen tudja ö, ha tök-é, vagy túrós étel. (Verseghy Ferenc 137/12). - 1850: Csak a tököt sem tudja a túrós ételtől megválasztani. (Ballagi Mór 1.7566). - Azt sem tudja, tök-e vagy túrós étel. (Ballagi Mór 1.7622). - 1851: Igen tudja ö, ha tök-e vagy turós étek. (Erdélyi János 1.7899). - 1855: (Ballagi Mór 2.7566 és 7622 = Ballagi Mór 1.7566 és 7622). - 1856: Azt sem tudja, tök-e vagy turósétek. (Szabó Román 64). - 1873: Azt sem tudja tök-e vagy túrós étek. (Ballagi Mór 3/2.669/2) = 1890: (Sirisaka Andor 9)

1598 - 19. század. 20. századi használatra vonatkozó adat nem került elö. Manapság az „Azt sem tudja, hogy eszik-e vagy isszák”, illetve a „Halvány (segéd) fogalma sincs róla” helyettesíti.

Jelentése: Halvány sejtelme sincs róla, hogy kicsoda vagy micsoda.

János Baranyai Decsi, the Paremiographer. The first Hungarian collection of proverbs, the Adagiorvm graecolatinovngaricorvm chiliades quinque by the Székelyvásárhely schoolmaster and humanist scholar, János Baranyai Decsi, was published in Bártfa in 1598. In East Central Europe it was preceded only by a Czech collection and followed in 1618 by a Polish one. The first Russian collection was published in the $18^{\text {th }}$, the first Bulgarian and Romanian one in the $19^{\text {th }}$ century.

The model of this collection was a 1574 Basel edition of Latin phrases and quotations by Erasmus, Hadrianus Iunius, Gilbertus Cognatus and others. Decsi made a selection, omitting the Latin explanations and adding Hungarian equivalents or translations.

The 4827 Hungarian entries of the small 444 page book include about 900 proverbs, containing most of the known proverbs of earlier date found in Hungarian books and letters. Hundreds of Decsi's proverbs are known and used today in the same wording, others are found only in certain regions of the Hungarian language community, mainly in Transylvania, white a number of them have since fallen into oblivion, e.g. „It fits (there), like a stick into a quiver.” - In additions of proverbs found only in Hungarian, like „A common horse has scars on its back”, this collections includes already a number of proverbs known in severeal European languages, e.g. „Do not look a gift horse in the mouth”. A few of them are related to similar proverbs in some Slavonic languages, e.g. „To throw peas against the wall".

A great number of the proverbs of Baranyai Decsi have been included in the different editions of the Hungarian-Latin Dictionaries of Albert Szenci Molnár from 1611 on $(1621,1644,1703)$, and into the later ones revised by Ferenc Pápai Páriz and Péter Bod. They found their way into later proverb collections, like that of Péter Kis-Viczay (Kassa, 1713) and all the following ones. 